УДК: 004.021

Леонід Броніславович Каневський (кандидат технічних наук)

Максим Сергійович Повх

Сергій Миколайович Шумський

Національний університет оборони Украӥни імені Івана Черняховського, Київ, Украӥна

\title{
ПЕРСПЕКТИВИ КОМБНОВАНОГО ВИКОРИСТАННЯ ВИДОВИХ ЗАСОБІВ ПОВІТРЯНО-КОСМІЧНОГО БАЗУВАННЯ ДЛЯ ПІДВИЩЕННЯ ІНФОРМАТИВНОСТІ РОЗВІДУВАЛЬНОГО ЗАБЕЗПЕЧЕННЯ ВІЙСЬК (СИЛ)
}

У статті проведено аналіз можливостей виконання завдань розвідувального забезпечення військ (сил) щцодо визначення положення та прогнозування характеру дій противника за інформацією від видових засобів спостереження щзо базуються в повітряно-космічному просторі за досвідом антитерористичної операчії та операції Об'єднаних сил. Визначено, щчо існуючі підходи у Збройних Силах Украӥни є не достатніми і потребують розвитку та удосконалення.

3 метою часткового вирішення даної проблеми були розглянуті підходи щуодо комбінованого використання засобів повітряного та космічного базування. Запропоновано алгоритм для вибору оптимального способу добування достовірних відомостей про склад, угрупування, дії, наміри противника.

Впровадження запропонованих підходів дозволить: підвищити інформативність та повноту розвідувального забезпечення Збройних Силах України, щзо сприятиме організації та плануванню діяльності військ (сил) в операції Об'єднаних сил, більш раціонально розподіляти та використовувати ресурс технічних видів розвідки повітряно-космічно базування.

Ключові слова: космічні апарати подвійного призначення, геоінформачійні технології, безпілотні авіаційні комплекси, розвідувально-інформаційне забезпечення військ (сил).

\section{Вступ}

Ретроспективний аналіз збройних конфліктів за останні 100 років [1-3] вказує на те, що розвиток збройної боротьби перебуває в якісно новій стадії, коли вирішальна роль вже відводиться не багаточисельним арміям і величині калібру зброї, а високоточній неядерній зброї, яка за своєю руйнівною силою еквівалентна ядерній, a, інколи, й вище за неї. Загально відомі принципи, які сприяють перемозі $\epsilon$ дії на випередження противника, що можливо завдяки використанню достовірних даних високорозвиненої системи розвідувального забезпечення.

В рамках даної статті для розвитку та удосконалення видової розвідки, як складової системи воєнної розвідки пропонується розглянути засоби повітряно-космічно базування. До складу таких засобів варто віднести космічні апарати (КА) оптико-електроного моніторингу Земної поверхні (наприклад: КА "WorldWiew-1,-2,-3,-4", "Eros-B", "Pleiades-1B", “GeoEye-1", тощо), спеціалізовані літаки розвідки (наприклад: Су-24 МР, Ан-30Б, Ту-154, U-2, CN-235 CASA, тощо), а також безпілотні літальні апарати $з$ апаратурою фото та відеоспостереження (наприклад: RQ-4 Global Hawk, PD-1, Fly Eye, Лелека-100, Фурія, тощо).

Враховуючи досвід бойових дій на сході України варто відмітити, що на озброєні російського агресора $є$ далекобійні та всепогодні засоби ураження, які володіють високою мобільністю. Для ефективного протистояння жорстко постає питання щодо підвищення вимог до оперативності й достовірності отримання розвідувальних відомостей, точності визначення координат об'єктів (цілей) противника i часу передачі розвідувальних даних до споживача інформації. В такій ситуації актуальним $є$ пошук підходів до використання засобів повітрянокосмічно базування, де в обмежених умовах (відсутності своїх космічних систем та деяких технічних видів повітряної розвідки) виникає потреба оптимальної організації систематичного добування розвідувальних відомостей про противника.

Комплексування даних від засобів повітрянокосмічного базування може стати основою для тематичної обробка 3 можливістю всеосяжної оцінки противника, прогнозування характеру його дій та ефективного планування дії своїх військ (сил).

Постановка проблеми. Завдання добування інформації про противника із використанням високотехнологічних засобів повітряно-космічно базування вимагає застосування принципів системного аналізу і методів синтезу різночасових даних від фізично різних за своєю будовою засобів добування інформації. Для якісного процесу перетворення вхідного потоку окремих роз'єднаних відомостей від усіх засобів повітряно-космічно базування в єдиний завершений результат у вигляді відомостей про склад, угрупування, ймовірний характер дій і наміри противника варто розглянути можливості застосування геоінформаційних технологій. Основою для формування такого роду відомостей має стати тематична обробка даних 3 повітряно-космічних систем. Для цього виникає необхідність виділення основних її складових (фаз), дослідження логічних зв'язків комплексування різноструктурних даних з виділенням та подальшим вирішення виникаючих проблем.

В контексті вирішення даного завдання, розглянемо противника, як окремий елемент на Земній поверхні, що за своїм характером може бути складним (аеродром, склад озброєння тощо) чи простим (літак, танк, військовий автомобіль) 
об’єктом розвідки. Цільова функція тематичної обробки буде зводитись до детального аналізу, систематизації, повторної перевірки і підтвердженні отриманих в ході обробки інформаційних даних для представлення споживачу достовірних відомостей 3 оцінки противника.

Основна проблема повітряної розвідки із застосуванням видових засобів літаків та безпілотних літальних апаратів полягає в суперечності між великими розмірами площі, що оглядається, i незначними геометричними розмірами переважної більшості цілей, які розвідують, що призводить до виникнення величезних обсягів первинної розвідувальної інформації, обробка яких для вище зазначених систем i апаратів космічного базування $є$ різною $\mathrm{i}$ не упорядкованою по відношенню один до одного.

Для отримання шуканого результату 3 урахуванням теорії прийняття рішень перед безпосереднім процесом добування розвідувальних даних має передувати вибір альтернативи, як варіанту застосування засобу повітряно-космічного базування результати яких належатимуть континуальній множині $\{\mathrm{X}\}$.

В загальному вигляді функція корисності для прийняття рішення може бути представлена як $\Phi=[\mathrm{y}(\mathrm{x}), \mathrm{r}]$, де $\mathrm{x}=\left(\mathrm{x}_{\mathrm{i}}\right)_{\mathrm{i}=1}^{\mathrm{n}} \in \mathrm{X}$, відповідно у представляє собою частинні критерії і визначається як $\mathrm{y}=\left\{\mathrm{y}_{\mathrm{k}}\right\}_{\mathrm{k}=1}^{\mathrm{s}} \in \mathrm{M}=\left\{0 \leq \mathrm{y}_{\mathrm{k}} \leq \mathrm{A}_{\mathrm{k}}, \mathrm{k} \in[1, \mathrm{~s}]\right\}$, де $\mathrm{A}$ множина обмежень, a $\mathrm{r}$ множина можливих зовнішніх умов.

3 метою побудови ефективної розвідувальноінформаційної системи на основі засобів повітрянокосмічно базування постає задача вироблення таких підходів та побудови такої оптимальної ієрархічної системи, яка дозволила б проводити вибір найкращого варіанту добування інформації про противника 3 повітряно-космічного простору.

Аналіз останніх досліджень і публікацій. Аналіз сучасних принципів ведення збройної боротьби [1-5] вказує на те, що у ЗС провідних держав світу головні зусилля під час підготовки та ведення бойових дій спрямовані на досягнення інформаційної переваги над противником шляхом удосконалення системи управління силами i засобами розвідки. В зв'язку 3 цим, основні зусилля провідних країн світу зосереджені на вирішенні таких завдань: адаптації існуючих систем збору, обробки і розподілення інформації до функціонування в єдиному інформаційнокомунікаційному просторі та надання доступу військам (силам), що беруть участь у бойових діях, до даних всіх засобів розвідки, що знаходяться в цій мережі.

Порівнюючи Грузино-Осетинський конфлікт 2008 року із «турботливою» участю Російської Федерації [3] та досвіду подій на сході України (аналітичні дані з 2014 по 2018 роки з відкритих джерел [6-9]) можна побачити тенденцію та напрями розвитку російського агресора. Оцінка події 2008 року на території Грузії [3] свідчать про недостатність у повітряно-космічних силах Російської Федерації (РФ) сучасної високоточної зброї 3 супутниковою системою наведення, основною зброєю на той час залишалася звичайна бомба та некерована ракета. Практично повна відсутність застосування безпілотних авіаційних комплексів (БпАК). Не зважаючи на це командування угрупування збройних сил РФ використовували інформацію космічних систем спостереження. Цьому свідчать факти того, що 3 достатньо високою організованістю було знищено: авіаційний завод, декілька кораблів у Поті, всі аеродроми. Варто відмітити, що зазначені об'єкти $\epsilon$ стаціонарними i не вимагають високої оперативності уточнення відомостей про них, а їх координати $є$ незмінними у часі.

Розглядаючи діяльність російського агресора на оперативному та оперативно-тактичному рівнях можна дійти висновку, що інформація космічних систем розвідки або не використовувалась, або мала низьку ефективність (близьку до нуля). Це пояснюється тим, що бомбові удари 3 повітря по рухомим сухопутним військам Грузії проводились iз запізненням на одну дві доби, що давало можливість грузинському керівництву вчасно передислоковувати їх. Використання РФ дальнього стратегічного бомбардувальника ТУ-22-М для задач фотографування результатів власних бомбових ударів для оцінки ефективності виконання завдань призвели до того, що він був збитий зенітним ракетним комплексом «Бук-М1», відповідно подальше застосування літаківрозвідників МІГ-25MP, Су-25P, Су-24MP скоротилось у рази.

Невизначеність у точності оцінки координат дислокації грузинських військ, що відходили, не дозволили використати повітряні десанти i гелікоптерні рухомі загони мінування для ускладнення відходу грузинських військ. Підвищення оперативності та достовірності отримання таких розвідувальних відомостей можна було б компенсувати за рахунок систематичного використання БпАК чого не було зроблено.

Аналіз досвіду бойових дій на сході України протягом 2014-2018 років [6-9] вказує на те, що незаконні збройні формування під керівництвом РФ за рахунок своїх штатних підрозділів безпілотної авіації активно нарощують їх застосування. Безпілотні літальні апарати противника виконували завдання шляхом ведення оптико-електронної розвідки 3 метою виключення раптових дій Об'єднаних сил (особливо в період проведення ротації українських військових підрозділів), уточнення лінії розмежування та контроль діяльності свої військ. Протягом останнього року в [9] відмічено понад 650 випадків застосування БпАК противника, 3 них основна частина безпілотних літальних апаратів типу “Орлан-10”, “Форпост”, “Елерон”, “Гранат" та різні типи квадрокоптерів.

Оцінка характеру застосування БпАК та інтенсивність вогню противника в зоні проведення операції Об'єднаних сил (ООС), протягом доби, вказують на те, що вогневому ураженню артилерійського підрозділу передує розвідка об'єкту ураження. При цьому, на виконання завдання та дешифрування матеріалів повітряної розвідки БпАК противнику необхідно до 8 годин. Застосування літаків-розвідників переважно проводиться в періоди ротацій підрозділів Збройних Сил України, це пояснюється потребою протиборчої сторони у широкомаштабному добуванні різносторонніх розвідувальних даних.

Огляд останніх досліджень [3, 10] показує, окремі переваги використання космічної компоненти, літаків-розвідників та БпАК. В інших роботах $[5,11]$ виокремлюються та розвиваються напрями щодо перспективи використання космічних апаратів дистанційного зондування Землі, як систем подвійного призначення 3 метою 
інформаційно-розвідувального забезпечення військ (сил). Враховуючи відсутність комплексного дослідження питань об'єднання інформації від усіх можливих засобів повітрянокосмічно базування 3 метою виявлення переваг та проблемних питань у цьому напряму в рамках даної статті пропонується розглянути перспективи комбінованого використання засобів повітрянокосмічного базування щодо вибору оптимального способу розвідувального забезпечення військ (сил).

Мета статті - дослідити можливості комбінованого використання даних від засобів повітряно-космічного базування (КА оптикоелектронного моніторингу Земної поверхні, літаків фото-розвідки, БпАК) для підвищення повноти та достовірності відомостей про противника.

\section{Виклад основного матеріалу дослідження}

Проведений огляд сучасних тенденцій ведення збройної боротьби вказує на необхідність пошуку нових, більш дієвих підходів до проведення заходів розвідувального забезпечення за інформацією від видових засобів повітряного та космічного базування у Збройних Сил України. Актуальним залишається питання розробки та впровадження інтегрованої системи управління та розвідки, як єдиного інформаційного простору, 3 можливістю використання будь-яким споживачем усієї необхідної інформації.

Якщо активне застосування в зоні проведення OОС БпАК (PD-1, Лелека-100, Фурія, Мара, тощо) дозволило підвищити оперативність отримання розвідувальної інформації, у порівнянні 3 літаками-розвідниками та КА, то питання повноти та високої достовірності залишається відкритим. В рамках формалізованого в статті завдання на прикладі воєнного дешифрування матеріалів повітряної розвідки, де кінцевим джерелом із усієї сукупності повітряно-космічних систем приймемо БпАК. Відповідно до цього варто зауважити, що крім суперечності між великими розмірами площі, що оглядається, i незначними геометричними розмірами переважної більшості цілей, які розвідують, ще добавиться проблема пробації воєнного дешифрування, що на сьогоднішній день проводиться оператором, який обмежений фізичними характеристика та своєю кваліфікацією.

У вузькому розумінні процес добування відомостей про противника із застосуванням КА чи літаків-розвідників і навіть БпАК буде мати однаковий характер i складатиметься 3 таких основних складових, як: аналіз, усвідомлення, постановка завдання; планування на виконання; тематична обробка отриманих даних та формування звітно-інформаційних документів. Узагальнення окремо отриманих відомостей про противника проводиться у спеціально визначених структурних підрозділах і як правило до самих виконавців таке узагальнення не надходить. Нажаль відсутність відповідного зворотного зв'язку аж ніяк не сприяє плануванню роботи цих засобів окремо або при їх спільному застосуванні. А відсутність на сьогоднішній день підходу щодо планування комплексування даних від різних засобів повітряно-космічного базування не дозволяє в повній мірі виділяти нові розвідувальні ознаки та в повній мірі оцінити ймовірний характер дій противника. Таким чином, для прикладу, де кінцевим джерелом із усієї сукупності повітряно-космічних систем буде БпАК. Апріорними даними для його планування i застосування має стати довідково-інформаційна система на базі геоінформаційних технологій наповнення якої необхідно проводити на основі космічних знімків у видимому діапазоні 3 розрізненістю $\sim 0,5 \mathrm{M}$ та можливістю автоматизованого оцінювання зміни обстановки у часі з переривом не більше 3 діб.

Додатково використання геоінформаційної системи буде спрощувати вирішення таких основних завдань:

доведення до органів управління та військ (сил) цифрової картографічної інформації про місцевість і об'єкти на ній;

генералізацію (масштабування) цифрової картографічної інформації;

створення, розповсюдження і накопичення в електронному вигляді графічних документів.

Іншим прикладом $\epsilon$ комплексування різноструктурних даних в межах одного часового інтервалу (протягом першої половини дня), де данні про один і той самий об'єкт отримані від БпАК це - фотознімок у видимому діапазоні, а від КА дистанційного зондування Землі багатоспектральний знімок. Такий підхід дозволяе виділити зв'язок $з$ просторовими і спектральними аналітичними моделями, а при наявності бібліотек спектральних еталонів дозволить використовувати спектрально-просторовий (субпіксельний) аналіз результатом якого повинна стати автоматична ідентифікація наземних об'єктів на поверхні Землі.

Для удосконалення процесу організації збору інформації про противника в ході проведення ООС iз використанням засобів видового спостереження повітряно-космічного базування пропонується проводити комплексування даних від цих джерел за структурно-логічною схемою поданою на рис. 1.

По суті основною відправною точкою реалізації роботи структурно-логічної схеми комплексування даних 3 різних засобів повітрянокосмічно базування $\epsilon$ постановка завдання. Слід розуміти, що головна залежність вироблення необхідного завдання для подальшого забезпечення військ (сил) розвідувальною інформацією буде пов'язана не лише 3 потребами добування розвідувальних відомостей про противника, a й від тактико-технічних характеристик (ТTX) доступних на момент виконання завдання видових засобів спостереження повітряно-космічного базування, вибір яких при плануванні та застосуванні буде здійснюватися на основі рішення багатокритеріальної задачі на що додатково впливатимуть фактори природного чи антропогенного характеру (утому числі наявність протиборчих систем противника, наприклад, засобів радіоелектронної боротьби). Також на цей процес впливатиме апріорна розвідувальна інформація, яка паралельно може надходити, як по каналам оперативної інформації так і по каналам від спеціалізованої бази даних (БД).

Основним принципом побудови добування розвідувальних відомостей про противника має стати оптимальний розподіл зусиль між засобами повітряно-космічного базування. В рамках існуючого протиріччя, постає завдання щодо вирішення багатокритеріальної задачі яка потребує вибору достатніх засобів добування розвідувальних даних та визначення послідовності 
їх застосування. Оптимізаційний підхід передбачає використання математичних моделей і критерію оптимізації в явному вигляді. Основою для вирішення такої задачі є пошук альтернативи, яка $\epsilon$ найкращою 3 точки зору деякого критерію. Такий підхід дає можливість підвищити якість рішення за рахунок таких факторів:

дозволяє знаходити варіанти розв'язку задачі при різних значеннях реальних обмежень на змінні

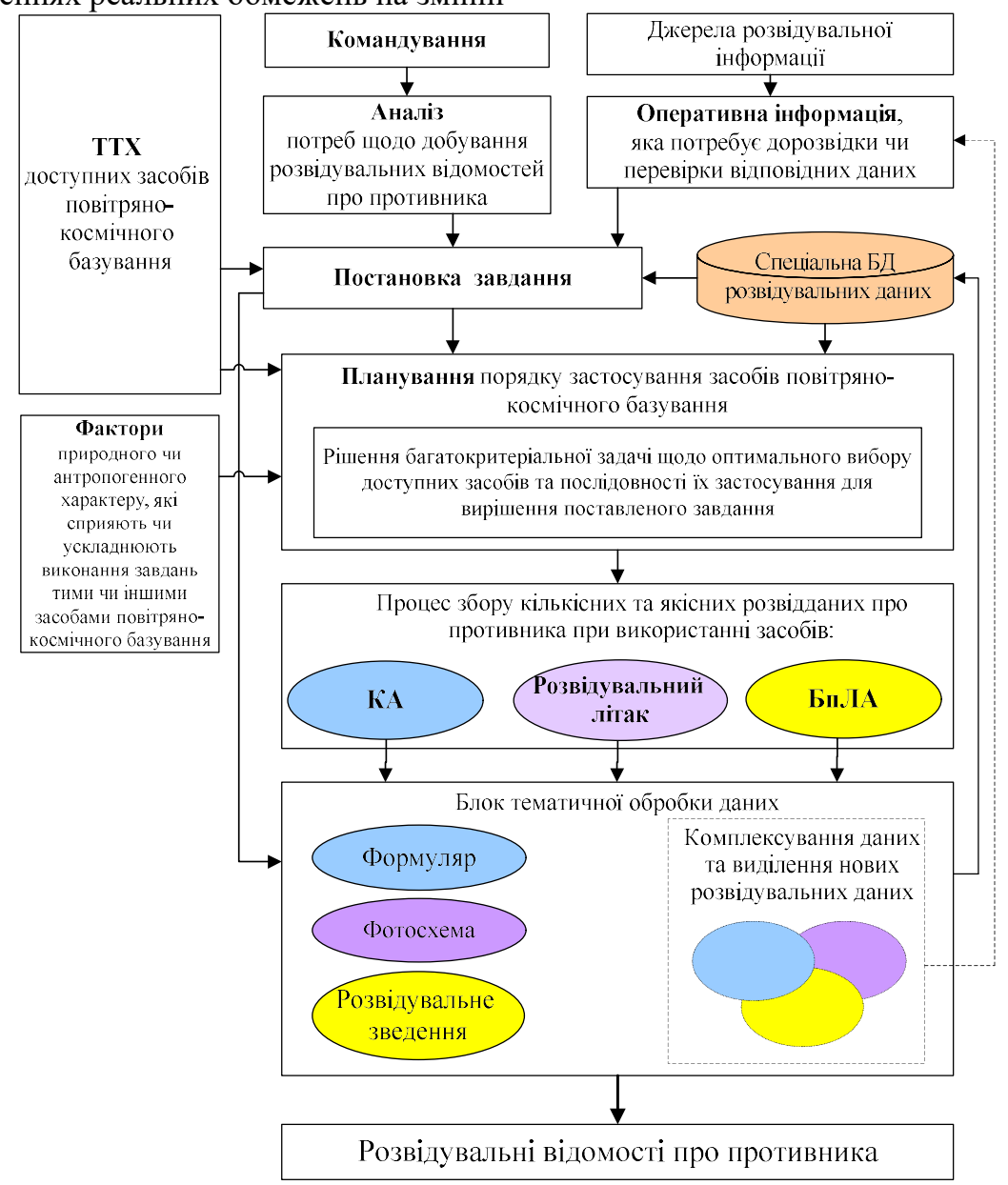

Рис. 1. Структурно-логічна схема комплексування даних з різних засобів видового спостереження повітряно-космічно базування

Відповідно до цього на схемі, що представлена на рис. 1 запропоновано ввести блок формування та узагальнення факторів які сприятимуть або ускладнюватимуть виконання завдань i враховуватимуться в процесі планування при вирішенні багатокритеріальної задачі. 3 урахуванням математичної формалізації завдання в певний фіксований момент часу при прийнятті рішення щодо застосування того чи іншого засобу повітряно-космічного базування вектор $r$ прийме фіксоване значення. В такому випадку функція корисності для прийняття рішення може бути представлена скалярною згорткою часткових критеріїв [12]:

$$
\Phi=[\mathrm{y}(\mathrm{x}), \mathrm{r}]_{\mathrm{r}=\mathrm{r}^{\mathrm{o}}}=\mathrm{Y}[\mathrm{y}(\mathrm{x}), \mathrm{r}]^{0},
$$

де: $\mathrm{Y}[\mathrm{y}(\mathrm{x}), \mathrm{r}]^{0}$ - скалярна згортка побудована за схемою компромісів, адекватної заданій ситуації.

Якщо вектор критеріїв $\mathrm{y}(\mathrm{x})$ пронумерований вектором обмежень А з урахуванням початкових умов у вигляді трьох основних складових, таких як: ТТХ засобів повітряно-космічного базування; очікуваний результат відповідно до поставленого завдання; данні від спеціалізованої бази

та різних початкових умовах.

дозволяє спростити процедуру вибору кращого рішення завдяки використанню аналітичних критеріїв, при цьому можна одночасно використати декілька критеріїв;

наявність множини методів розв'язання задач динамічної оптимізації дає можливість вибрати кращу альтернативу.

. 
створення спеціалізованої бази розвідувальних даних, доступ до якої для всіх відповідних рівнів має бути організований саме із впровадженням автоматизованої системи управління й формування єдиного інформаційнокомунікаційного простору. Відповідно, такі дані мають стати основою для планування щодо застосування засобів видового спостереження повітряно-космічного базування та усвідомлення завдань командирами на тактичному piвні. А варіанти тематичної обробки доцільно було б оптимізувати за напрямами добування інформації, що представлені на рис.2.

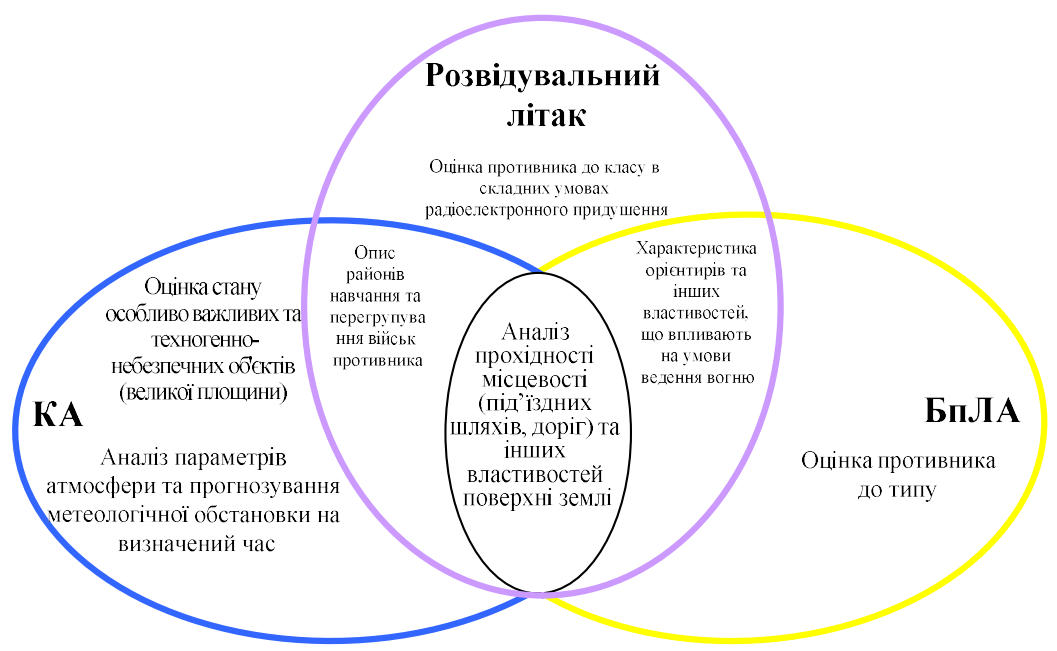

Рис. 2. Характеристика даних, які варто використовувати в процесі комплексування

3 рис. 2 можна побачити, що при відповідному плануванні та застосуванні КА і розвідувальних літаків об'єднання інформації можливо проводити за двома напрямами: опис районів спостереження та перегрупування військ противника i аналіз прохідності місцевості та інших властивостей поверхні Землі. тоді, як при застосуванні КА і БпЛА лише за одним (аналіз прохідності місцевості та інших властивостей поверхні Землі). При цьому слід розуміти, що таке подання не обмежується лише зазначеними напрямами. Важливо відмітити той факт, що данні від КА можна використовувати, як апріорні для планування i застосування БпЛА 3 метою уточнення даних про противника та його оцінки до типу об'єктів шляхом дешифрування матеріалів повітряної розвідки отриманих 3 БпЛА. Такий підхід обмежується лише творчістю та кваліфікацією користувачів даної інформації. Але ефективне використання повітряно-космічної компоненти неможливе без створення багатофункціональної та інтегрованої інфраструктури систем обміну інформацією між добувними підрозділами i споживачами. А комплексування інформації від КА, літаків та БпЛА на різних рівнях ії отримання і проходження дозволить заповнювати пробіли інформаційнорозвідувальної діяльності та більш повно розкривати наміри та дії противника.

\section{Висновки й перспективи подальших досліджень}

Проведений в роботі огляд сучасних тенденцій

\section{Лimepamypa}

1. Історія війн та військового мистецтва. Навч. Посібник / Під заг.ред. С. І. Береснева та інш. - Х.: ХУ ПС, 2007. 230 c. 2. Розвиток військового мистецтва в локальних війнах 90-х років ХХ ст. - К.: НАУО, 2003. - 109 с. 3. Дробаха Г.А. Розвиток тактики дій засобів повітряного нападу в локальних конфліктах XXI століття / Г. А. Дробаха, С. М. Піскунов, І. М. Тихонов // Збірник наукових праць. - Житомир : ЖВІ ДУТ, 2015. - Випуск 10. - C. 87-94. 4. Davis J.R. Defending Future Hybrid Threats / J.R. Davis // Military Review. - Fort Leavenworth, September-October 2013. - No.5. - P. 21- 29. 5. Попов М. О. Видова космічна розвідка в локальних ведення збройної боротьби дозволив виробити ряд підходів реалізація яких дозволить: підвищити повноту та достовірність розвідувально забезпечення Збройних Силах України. Це сприятиме організації та плануванню діяльності військ (сил) в операції Об'єднаних сил і дасть змогу більш раціонально розподілити та використовувати ресурс засобів видового спостереження повітряно-космічно базування. Для цього запропоновано вирішення багатокритеріальної задачі за схемою компромісів обмеженою лінеаризованою моделюю щодо вибору достатніх засобів добування розвідувальних даних та визначення послідовності їх застосування. Створення спеціалізованої бази розвідувальних даних, мають стати не лише апріорною основою для планування із застосування засобів видового спостереження повітряно-космічного базування, а за рахунок доступу до неї споживачів на усіх рівнях (включаючи тактичний).

Подальші дослідження необхідно спрямувати на вирішення проблем щодо розширення можливостей використання даних космічного сегменту за рахунок побудови приймальних комплексів інформації 3 іноземних космічних апаратів. Удосконалення методів комплексування різнорідної інформації на основі геоінформаційних технологій. Розширення можливостей застосування БпАК в складних умовах радіоелектронного подавлення зі сторони противника.

військових конфліктах / M. О Попов, M. В. Топольницький, В. О. Подліпаєв // Наука і оборона. 2015. - № 1. - C. 25-35. 6. https://www.facebook.com/ pressjfo.news/?ref=search (Сторінка Операція об'єднаних сил / Joint Forces Operation). 7. https://ukr.media/news-ato/ 8. https://112.ua/ato.

9. https://www.slovoidilo.ua/2019/02/17/karta/karta-oos-

sytuacziya-sxodi-ukrayiny-17-lyutoho. $\quad \mathbf{1 0}$. Zibtsev $\mathbf{S}$. Wildfires Risk Reduction From Forests Contaminated by Radionuclides: A Case Study of the Chernobyl Nuclear Power Plant Exclusion Zone / S. Zibtsev // Living with fire Addressing global change thought integrated fire 
management (International wildland fire conference Sun City, South Africa, 9-13 May 2011). - Sun City, 2011. - P. 23. 11. Ковбасюк С. В. Методичні підходи до процесу дешифрування даних дистанційного зондування Землі середньої розрізненості в інтересах національної безпеки й оборони / С. В. Ковбасюк, Д. Л. Федорчук, Г.
Д. Носова // Збірник наукових праць. - Житомир : ЖВІ ДУТ, 2015. - Випуск 10. - С. 87-94. 12. Многокритериальные решения: модели и методы: монография / А.Н.Воронин, Ю.К.Зиатдинов, М.В.Куклинский. - К.: НАУ, 2011. - 348 с.

\title{
ПЕРСПЕКТИВЫ КОМБИНИРОВАННОГО ИСПОЛЬЗОВАНИЯ ВИДОВЫХ СРЕДСТВ ВОЗДУШНО-КОСМИЧЕСКОГО БАЗИРОВАНИЯ ДЛЯ ПОВЫШЕНИЯ ИНФОРМАТИВНОСТИ РАЗВЕДЫВАТЕЛЬНОГО ОБЕСПЕЧЕНИЯ ВОЙСК (СИЛ)
}

\author{
Леонид Брониславович Каневский (кандидат технических наук) \\ Максим Сергійович Повх \\ Сергій Миколайович Шумський
}

\section{Национальный университет обороны Украины имени И. Черняховського, Киев, Украӥна}

В статье проведен анализ возможностей выполнения заданий разведывательного обеспечения войск (сил) относительно определения положения и прогнозирования характера действий противника по информации от видовых средств наблюдения что базируются в воздушно-космическом пространстве за опытом антитеррористической операции и операџии Объединенньх сил. Определено, что существующие подходы в Вооруженных Силах Украины являются не достаточными и нуждаются развития и усовершенствования.

С иелью частичного решения данной проблемы были рассмотрены подходы комплексного использования средств воздушно-космического базирования. Предложен алгоритм для выбора оптимального способа добывания достоверных сведений о составе группировке, действий и намерений противника.

Внедрение предложенных подходов позволит: повысить информативность разведывательного обеспечения Вооруженных Силах Украины, что будет способствовать организации и планированию деятельности войск (сил) в операции Объединенных сил, более рационально распределить и использовать ресурс средств воздушно-космического базирования.

Ключевые слова: космические аппараты двойного назначения, геоинформационные технологии, беспилотные авиационные комплексы, информачионного обеспечения войск (сил).

\section{PROSPECTS OF COMBINED USE OF SPECIFIC AIRCRAFT BASES FOR IMPROVEMENT OF INFORMATIVE SENSITIVENESS}

\author{
Leonid Kanevskyy (Candidate of technical sciences) \\ Maksym Povkh \\ Serhii Shumskyi
}

\section{National Defense University of Ukraine named after Ivan Cherniakhovskyi, Kyiv, Ukraine}

The article analyzes the capabilities of troops (forces) informational support task performance concerning the enemy position and modus operandi based on the Anti-Terrorist Operation and Joint Forces Operation. It was identified that currently the approaches of intelligence and informational support existing in the Armed Forces of Ukraine in the area of military security context are insufficient and this situation requires searching for some methods for raising its efficiency.

For the partial solution of this problem there have been examined the approaches of the air and space basing assets combined use. The algorithm was suggested for choosing the optimal way of reliable data acquisition concerning the enemy forces composition, activities and intentions.

The introduction of suggested ways will enable to: increase the intelligence and informational support awareness of the Armed Forces of Ukraine promoting better troops (forces) activity organization and planning in the Joint Forces Operation, to distribute and utilize the resources of the air and space basing assets more efficiently.

Key words: dual-purpose space vehicles, geo-informational technologies, unmanned areal complexes, troops (forces) informational support.

\section{References}

1. History of wars and martial arts. Educ. Manual / Under the editorship SI Beresneva et al. - X .: ХУ ПС, 2007. - 230 p. 2. The development of martial arts in the local wars of the 90 's of the twentieth century. - K .: NAUO, 2003. - 109 p.

3. Drobakh GA The development of tactics of air attack in local conflicts of the XXI century / GA Drobakh, SM Piskunov, IM Tikhonov // Collection of scientific works. Zhytomyr: THE LIFE OF DUT, 2015. - Issue 10. - P. 87-94. 4. Davis J.R. Defending Future Hybrid Threats / J.R. Davis // Military Review. - Fort Leavenworth, September-October 2013. - No.5. - P. 21- 29. 5. Popov MO Specific space exploration in local military conflicts / MA Popov, MV Topolnitsky, VO Podlipayev // Science and Defense. - 2015. - № 1. - P. 25-35. 6. https://www.facebook.com/pressjfo. news/?ref=search (Joint Forces Operation page). 7. https://en.media/news-ato/ 8. https://112.ua/ato.
9. https://www.slovoidilo.ua/2019/02/17/karta/karta-oossytuacziya-sxodi-ukrayiny-17-lyutoho. $\quad \mathbf{1 0}$. Zibtsev S. Wildfires Risk Reduction From Forests Contaminated by Radionuclides: A Case Study of the Chernobyl Nuclear Power Plant Exclusion Zone / S. Zibtsev // Living with fire Addressing global change thought integrated fire management (International Wildland Fire Conference Sun City, South Africa, 9-13 May 2011). - Sun City, 2011. - P. 23. 11. Kovbasyuk SV Methodical approaches to the process of decryption of data of remote sensing of the Earth of average disparity in the interests of national security and defense / SV Kovbasyuk, DL Fedorchuk, G. D. Nosova // Collection of scientific works. - Zhytomyr: THE LIFE OF DUT, 2015. - Issue 10. - P. 87-94. 12. Multicriteria solutions: models and methods: a monograph / AN Voronin, Yu.K. Ziotdinov, MV Kuklinsky. - K .: NAU, 2011. - 348 p. 